Вељко Ж. Брборић

371.3::811.163.41'35

Универзитет у Београду

https://doi.org/10.18485/ai_cirilica.2017.ch6

Филолошки факултет

\title{
МЕСТО И УЛОГА СРПСКОГ ЈЕЗИКА КАО НАСТАВНОГ ПРЕДМЕТА У ОБРАЗОВНОМ СИСТЕМУ ${ }^{1}$
}

У раду ће бити речи о статусу Српског језика као наставног предмета у образовном систему - од основне школе до универзитета. Заправо, биће речи о заступљености Српског језика у наставним плановима и програмима од основне школе до универзитетске наставе. Урадићемо кратак осврт и на прошлост овог проблема, као и поређење са неким језицима у окружењу. Биће речи и о неким предлозима како да се статус Српског језика у образовном систему поправи. По нашим сазнањима, најлошије „стојимо“ у млађим разредима основне школе, где је заостајање у броју часова осетно у односу на језике у окружењу и велике европске језике. Заостајање је видно и у старијим разредима основне школе, док је у средњим школама посреди прилична неуједначеност. Статус Српског језика на универзитетском нивоу изван филолошких/филозофских и учитељских факултета није решен.

Кључне речи: српски језик, образовни систем, број часова, наставни планови и програми

1 Рад је резултат рада на пројекту Срйски језик и юеі̄oви ресурси: иесерија, ойис и йримена (бр. 178006), које финансира Министарство просвете, науке и технолошког развоја Републике Србије. 


\section{1. Увод}

Од почетка нашег школства Српски језик као наставни предмет имао је важну и истакнуту улогу у образовном систему. Такву улогу матерњи језик има и код других народа и у другим образовним системима. Ако се осврнемо на историју нашег школства, видећемо да су у прошлости место и улога Српског језика, као наставног предмета, били много бољи и да је Српски језик (Српски језик и књижевност) био увек најистакнутији и најзначајнији предмет. Стицајем различитих околности, нарочито у другој половини двадесетога века наш предмет је доживео озбиљно смањење броја часова, што се одразило и на програмске садржаје. О чему се заправо ради? Место и улога једног предмета у настави и наставном процесу огледа се у његовом месту у званичним документима и то је на првом месту наставни план и програм. Ту се лако види број часова (недељни и годишњи) и програмски садржај предмета (језик, књижевност и култура изражавања), тј. оно што се обрађује на наставним часовима, појединачно у сваком разреду. Ако је број часова реалан и прихватљив и улога наставног предмета је јасно дефинисана, онда ће и однос према матерњем језику у образовном систему бити сигурнији и срећнији (Брборић: 2004). Зато ћемо дати кратак увид у прошлост наших планова и програма и статус српског језика у њима. ${ }^{2}$ Сведоци смо да се у Србији, последњих година, на овај проблем гледа на посве неуједначен начин. Наиме, струка је често указивала на недовољан број часова и потребу да се он повећа. Истовремено се увођењем нових пред-

2 Наше школство нема тако дугу традицију. Наиме, школство у правом смислу речи добијамо на почетку деветнаестог века, у устаничкој Србији. Разуме се да је образовања било и пре тога, али овде мислимо на образовни процес по утврђеним наставним плановима и програмима. 
мета и потребом учења више страних језика помињала и могућност додатног смањења броја часова српског језика у основној школи и средњим школама. Тако је Друштво за српски језик и књижевност Србије било принуђено да пре извесног времена упути отворени апел, како би се заштитио статус српског језика у школском систему. ${ }^{3}$ Било је то после најаве да се у неким стручним школама недељни фонд часова српског језика смањи са три на два часа (средње медицинске школе).

\section{2. Српски језик у основној школи}

Ако пођемо од актуелног (савременог) стања у нашим основним школама и места и улоге Српског језика као наставног предмета, онда морамо констатовати следеће чињенице. Данас се Српски језик, гледајући кроз наставни план, реализује на следећи начин. Од првог до петог разреда имамо по 5 часова недељно, а у шестом, седмом и осмом разреду по 4 часа недељно (Табела 1). Статистика показује да је настави Српског језика у основној

Апелом је јасно тражено да се број часова не смањује ни на једном образовном нивоу. Посебно је било речи о неким средњим стручним школама, где је већ био смањен број часова или је смањење било у најави, али је апелом јасно показана и образложена потреба да се број часова Српског језика повећа. Апел је упућен: Министарству просвете, науке и технолошког развоја Републике Србије, Одбору за образовање Народне скупштине Републике Србије, Национално-просветном савету Републике Србије, Савету за стручно образовање и образовање одраслих Републике Србије, Заводу за унапређивање образовања и васпитања, Заводу за вредновање квалитета образовања и васпитања, Филолошком факултету Универзитета у Београду, Филозофском факултету Универзитета у Новом Саду, Филозофском факултету Универзитета у Нишу, Филолошко-уметничком факултету Универзитета у Крагујевцу, Матици српској, Српској академији наука и уметности и Јавности. 
школи намењено 350 часова (26.4\%), настави књижевности 510 часова (38.5\%), за наставу културе изражавања 381 час (28.5\%), док 95 часова припада настави почетног читања и писања у првом разреду основне школе (7.2\%). По нашим сазнањима, настава језика (граматике) се у основној школи солидно реализује и часови језика се не „жртвују“у корист часова (наставе) књижевности. Ипак, вреди размислити да ли је овај однос добар и да ли су нужне неке мање корекције.

\begin{tabular}{|l|c|c|c|c|c|}
\hline & $\begin{array}{c}\text { недељно } \\
\text { часова }\end{array}$ & $\begin{array}{c}\text { годишње } \\
\text { часова }\end{array}$ & $\begin{array}{c}\text { настава } \\
\text { језика }\end{array}$ & $\begin{array}{c}\text { настава } \\
\text { књижевности }\end{array}$ & $\begin{array}{c}\text { културажавања } \\
\text { изражав }\end{array}$ \\
\hline $\begin{array}{l}\text { ПРВИ } \\
\text { РАЗРЕД }\end{array}$ & 5 & 180 & 15 & 40 & 30 \\
\hline $\begin{array}{l}\text { ДРУГИ } \\
\text { РАЗРЕД }\end{array}$ & 5 & 180 & 40 & 80 & 60 \\
\hline $\begin{array}{l}\text { ТРЕЋИ } \\
\text { РАЗРЕД }\end{array}$ & 5 & 180 & 40 & 80 & 60 \\
\hline $\begin{array}{l}\text { ЧЕТВРТИ } \\
\text { РАЗРЕД }\end{array}$ & 5 & 180 & 45 & 80 & 55 \\
\hline $\begin{array}{l}\text { ПЕТИ } \\
\text { РАЗРЕД }\end{array}$ & 5 & 180 & 60 & 60 & 60 \\
\hline $\begin{array}{l}\text { ШЕСТИ } \\
\text { РАЗРЕД }\end{array}$ & 4 & 144 & 50 & 55 & 35 \\
\hline $\begin{array}{l}\text { СЕДМИ } \\
\text { РАЗРЕД }\end{array}$ & 4 & 144 & 50 & 55 & 36 \\
\hline $\begin{array}{l}\text { ОСМИ } \\
\text { РАЗРЕД }\end{array}$ & 4 & 136 & 45 & 55 & 35 \\
\hline
\end{tabular}

Табела 1. Часови Срӣскоі̄ језика у основној школи

Овде ћемо се укратко осврнути на број часова Српског језика у основној школи као наставног предмета, у прошлости. Средином деветнаестога века, 1844. године, по наставном плану и програму имали смо и по 10 часова недељно Српског језика у неким разредима. Године 1891. број часова у млађим разредима био је неуједначен: у 
првом разреду је било 10 часова, у другом 8, док је у трећем и четвртом разреду било по 5 часова. Просек је тада био по 7 часова недељно, уз постојање и других предмета са програмским садржајима блиским нашем језику (Лейо йuсане, Краснойuс...). Мање одступање налазимо 1899. године. Тада смо у првом и другом разреду имали по осам часова, а у трећем и четвртом разреду по 6 часова. Просек је опет био по 7 часова недељно (Стевановић 1977). После Првог светског рата, 1926. године, у прва четири разреда основне школе сусрећемо по 7 часова намењених матерњем језику (назив предмета је био српско-хрватски језик, у једном периоду чак и српско-хрватско-словеначки), ${ }^{4}$ али смо имали и предмете Лейо йисане, Краснойис, као и предмете с називима који су упућивали на предметност матерњег језика. ${ }^{5}$ Између два светска рата статус Српског језика као наставног предмета у образовном систему био је прилично добар, посебно када се посматра из данашње перспективе. Практично смо кроз цео деветнаести век и у првој половини двадесетога, у млађим разредима основне школе, имали просечно по седам часова недељно, а понекад и више од тога броја.

После Другог светског рата опет смо у млађим разредима имали солидан број часова матерњег језика. Тако смо школске 1947/8. године имали у првом и другом разреду по 10 часова, у трећем и четвртом 6 часова (просек 8 часова недељно), школске 1948/9. у првом и другом разреду по 10 часова, а у трећем и четвртом по 6 часова

4 Овде је видна аналогија са називом државе. У једном периоду, после стварања прве Југославије (1918), званичан назив језика био је српско-хрватско-словеначки. Тај назив се сусретао све до 1929. године.

5 Током Другог светског рата у Србији се у једном тренутку настава српског језика, по наставном плану и програму, реализовала са просеком од 9 часова: први и други разред по 11 часова, трећи и четврти разред по 7 часова. 
недељно (просек 8 часова недељно), а школске 1950/51. године у првом разреду 9 часова, у другом 10 , у трећем 7 и у четвртом 6 (просек 8 часова недељно). ${ }^{6}$ Ипак, смањење броја часова матерњег језика десило се нешто касније.

До тада су старији разреди основне школе службено били млађи разреди гимназије и број часова је био неуједначен. Крајем педесетих година двадесетога века млађи разреди гимназије претварају се у старије разреде основне школе и тада се успоставља систем обавезног основног образовања у трајању од осам година и он је у суштини сачуван до данас. Уследило је „жртвовање“ матерњег језика као наставног предмета. Тако смо 1959. године већ имали основну школу у којој смо у првом, другом и трећем разреду имали по 6 часова недељно матерњег језика, у четвртом, петом и шестом разреду по 5 часова и у седмом и осмом разреду по четири часа недељно. Тако је просек доживео осетно смањење - у млађим разредима је пао испод 6 часова недељно, а у основношколском школовању на 5,1 час недељно. После неколико година (1963. године) било је мањег успона, да бисмо у другој половини двадесетог века, када је школска недеља са шест прешла на пет радних дана, дошли до броја часова какав је и у данашњем обавезном осмогодишњем школовању (Табела 1).

Дакле, некада смо имали и по 10 или 9 часова недељно, док данас имамо у основној школи просек од 4,6 часова недељно (укупно 32 часа недељно у основној школи, од првог до осмог разреда). Неспорно је да је увођењем обавезног основног образовања Српски језик, као наставни предмет, остао ускраћен за велики број часова. То се види појединачно по разредима и у укупном осмогодишњем просеку.

6 Ово је био период, после Другог светског рата, када су скоро сваке године рађени нови наставни планови и програми. У настави језика није било великих промена, али је зато настава књижевности доживела велике промене и јасну „идеологизацију“. 
Овде се вреди, подсећања ради, осврнути на број часова матерњег језика код других народа и култура. Тако данас Французи имају од првог до четвртог разреда основне школе по 10 часова недељно, Турци у првом и другом разреду по 10 часова, у трећем и четвртом разреду по 8 (просечно 9 часова недељно). Руси имају у првом и другом разреду по 9 часова, у трећем 8, а у четвртом 7 (просек 8,25 часова недељно) и то је скоро дупло више од нас. Од нас су бољи Словенци и Мађари, док Украјинци и Белоруси имају, као и ми, по 5 часова недељно (Драгићевић 2015).

Ако погледамо колики је број часова матерњег језика у вишим разредима основне школе, и ту ћемо констатовати да заостајемо за Белорусијом, Француском, Турском, Словенијом, Русијом и многим европским земљама. Заостајање је видно и у основним и у средњим школама (Драгићевић 2015).

\section{3. Српски језик у средњој школи}

Настава српског језика и књижевности у средњим школама, ако се погледа укупан фонд часова, стицајем разних околности, смањена је после Другог светског рата. Прво је Српски језик претрпео „удар“ увођења нових предмета, а потом и смањењем радне недеље са шест на пет радних дана. Место и улогу Српског језика додатно је ослабило (не)оправдано јачање наставе књижевности. Наиме, у средњој школи се предмет званично зове у свим школским документима Српски језик и књижевност, и то није спорно. Ипак, ако се пажљиво погледа наставни програм, онда је лако утврдити да је највише часова намењено настави књижевности, а неупоредиво мањи број настави језика (граматике) и настави културе изражавања. Ако узмемо за пример гимназију општег типа, у којој ученици сваке године (од првог до четвртог) имају по четири часа недељно нашег предмета, онда ћемо доћи 
до следећих чињеница и података. ${ }^{7}$ У првој години средње школе наши гимназијалци имају 140 часова - 32 језика, 88 књижевности и 20 часова за културу изражавања. Други разред предвића 148 часова - 30 за наставу језика, 91 за наставу књижевности и 27 за културу изражавања. Трећи разред предвиђа 144 часа - 34 за наставу језика, 90 за наставу књижевности и 20 за културу изражавања; док у четвртом разреду имамо 128 часова и то: 30 за наставу језика, 80 за наставу књижевности, а 18 за културу изражавања (Табела 2). Статистика каже да наши гимназијалци (општи смер) имају укупно 560 часова и да од тога на реализацију програмских садржаја из језика имамо 126 часова (22,5\%), за наставу књижевности 349 часова $(62,3 \%)$ и за наставу културе изражавања 85 часова (15,2\%).

\begin{tabular}{|l|c|c|c|c|c|}
\hline & $\begin{array}{c}\text { недељно } \\
\text { часова }\end{array}$ & $\begin{array}{c}\text { годишње } \\
\text { часова }\end{array}$ & $\begin{array}{c}\text { настава } \\
\text { језика }\end{array}$ & $\begin{array}{c}\text { настава } \\
\text { књижевности }\end{array}$ & $\begin{array}{c}\text { култура } \\
\text { изажавања }\end{array}$ \\
\hline $\begin{array}{l}\text { ПРВИ } \\
\text { РАЗРЕД }\end{array}$ & 4 & 140 & 32 & 88 & 20 \\
\hline $\begin{array}{l}\text { ДРУГИ } \\
\text { РАЗРЕД }\end{array}$ & 4 & 148 & 30 & 91 & 27 \\
\hline $\begin{array}{l}\text { ТРЕКИ } \\
\text { РАЗРЕД }\end{array}$ & 4 & 144 & 34 & 90 & 20 \\
\hline $\begin{array}{l}\text { ЧЕТВРТИ } \\
\text { РАЗРЕД }\end{array}$ & 4 & 128 & 30 & 80 & 18 \\
\hline
\end{tabular}

Табела 2. Часови Срйскої језика у среgюој иколи

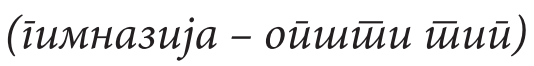

Дакле, по наставном плану и програму, за наставу језика предвиђено је нешто више од петине часова. Дода-

7 У гимназији општег типа имамо 560 часова за четири године, у гимназији природно-математичког типа тај број је мањи за седамдесетак часова, а у гимназији друштвено-језичког смера већи за седамдесетак часова. Четворогодишње стручне школе имају по три часа недељно и укупан фонд је око 420 часова током средњошколског образовања. 
тан проблем представља и сама реализација наставе. Често се говори о томе, и то без ваљаних аргумената и прихватљивих објашњења, да се и предвиђени број часова за наставу језика не реализује. Изговори су различити и нама неприхватљиви. ${ }^{8}$ Често се и овај број часова предвиђених за наставу језика „преусмерава“ за реализацију наставе књижевности. За ову појаву нису могућа ваљана објашњења, а она су често реалност у реализацији средњошколске наставе. Тако смо последњих година могли чути различите предлоге да се овакво стање исправи, па ни захтеви да се настава књижевности одвоји од наставе језика у нашем средњошколском образовању нису били реткост. ${ }^{9}$ За почетак бисмо били задовољни да се и овако скраћен број часова за наставу језика реализује, тј. да профе-

8 Понекад чујемо тумачења да ученици не воле граматику (као да их неко пита да ли воле хемију и биологију). Чак и када се часови намењени језику „пребаце“ у наставу књижевности, онда бисмо помислили да нам је настава књижевности добра, тј. одлична. Када се говори о реализацији наставе књижевности у средњој школи, онда се не сме прећи преко чињенице да наши средњошколци све мање читају, да многа дела „прескачу“ и да је реч о озбиљној кризи читања и рђавој реализацији и у настави књижевности. Поставља се отворено питање: ако се настава језика не реализује, а настава књижевности је у кризи, шта се онда ради на часовима Српског језика и књижевности. Нема сумње да је ово питање које би се могло поставити професорима који раде у нашим средњим школама. Истина, није проблем само код професора, али се о овоме мора разговарати и озбиљно и одговорно.

9 Наши наставни планови и програми за средње школе су прилично времешни. Званичан уџбеник од 1989. године је Грамайика срйскоі језика за іимназије и среgюе школе Живојина Станојчића и Љубомира Поповића. Реч је о захтевном уџбенику на 400 страна и он се не може реализовати са малим бројем часова. Прво издање овог уџбеника из 1989. године имало је

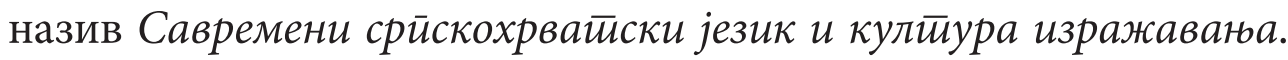
Одељак о култури изражавања (четрдесетак страна) написао је Стеван Мицић, али је он изостао у каснијим издањима. 
сори реализују постојећи наставни план и програм и садржаје који су предвиђени за наставу језика.

Остаје отворен проблем наставе у средњим стручним школама, како у оним које трају четири године, тако и у оним трогодишњим. Овде бисмо прво морали урадити реалне наставне програме, и то потпомоћи одговарајућом средњошколском граматиком за њих. Постојећа граматика апсолутно је мало употребљива у средњим стручним школама. То није потребно посебно доказивати.

4. Српски језик на универзитетском нивоу

О статусу Српској језика на универзитетском нивоу најбољи преглед даје се у објашњењима Милоша Ковачевића (Ковачевић 2012). Заправо, овде се даје добар попис статуса Српског језика на универзитетском нивоу и ово би могао бити, на неки начин, програмски текст. Неспорно се ту могу раздвојити неколико нивоа. Први је везан за место и улогу Српског језика на филолошким и филозофским факултетима на којима се изучава србистика. Други је место и улога Српског језика на учитељским (педагошким) факултетима, будући да учитељске компетенције из предметности српског језика имају невероватно важну улогу. Потом следе факултети, тј. студијске групе на којима се изучавају стране филологије (страни језици, књижевности и културе). Наравно не смеју се изгубити из вида ни факултети који припремају наставнички (професорски) кадар за рад у школама из различитих наставних предмета (Ковачевић 2012). И на крају остају факултети који спадају у категорију ненаставничких факултета. И овде би било места настави српског језика, функционалне писмености и језичке културе. 
Имамо студије србистике у Србији у шест универзитетских центара: Београд, Нови Сад, Ниш, Крагујевац, Нови Пазар ${ }^{10}$ и Приштина (са привременим седиштем у Косовској Митровици). У Републици Српској студије србистике имамо у Бањој Луци и Источном Сарајеву (Пале). На њима је приступ Српском језику поприлично неуједначен, мада ови наставни и научни центри помало и личе једни на друге, и то је добро. Ипак, разлике су видљиве и за ову прилику издвајамо неуједначен приступ језику и књижевности, што није неочекивано, посебно ако се има у виду традиција и свеукупне околности развоја нашег универзитетског образовања. Заправо, на универзитетима у Крагујевцу, Бањој Луци и Источном Сарајеву наставни планови и програми урађени су као двопредметни и имају уједначен (равноправни) приступ настави српског језика и књижевности. За разлику од њих, Београд, Нови Сад, Ниш и Приштина имају по две групе (смера), и на једној има предност језик, а на другој књижевност. Вреди напоменути да обе групе имају иста звања и ова подела се данас сматра наслеђеном, мада би се о оваквом приступу могло расправљати. ${ }^{11}$ У шестом универзитетском центру, оном у Новом Пазару, српска књижевност има предност над језичким дисциплинама, и он се у томе разликује од Београда, Новог Сада, Крагујевца, Ниша и Приштине и универзитета у Републици Српској. Можемо се оправдано питати зашто нема више сличности међу нашим србистичким центрима и какве то последице има по студенте уколико би они током сту-

\footnotetext{
10 Овде је реч о државном универзитету у Новом Пазару.

11 Некада се, истина неформално, говорило да су студенти који су завршили студијску групу на којој су предност имали језички предмети „виђени“ за основну школу, а они који су завршили студијску групу са више књижевности „позванији“ за средњу школу. Данас је ова теза изгубила актуелност и није предмет озбиљних разговора и оправданог приступа.
} 
дија хтели да промене факултет на коме студирају. ${ }^{12}$ Ово се односи и на мастер студије, јер су студенти понекад условљени уписом на мастер студије, ако су на једном факултету завршили студијску групу где је било више језичких предмета, а желе наставити мастер студије на другом факултету. Овде им је понекад избор ограничен и ми не разумемо овакав приступ.

Када су у питању два универзитетска центра у Републици Српској (Српско Сарајево и Бања Лука), тамо је однос Српског језика и књижевности поприлично уједначен, тј. Српски језик и књижевност у наставним плановима и програмима имају равноправан статус и посреди је нека врста двопредметне наставе, као и у Крагујевцу.

Недавно је у Тршићу отворен Образовно-културни центар „Вук Караџић“. Волели бисмо да једна од првих активности тога Центра буде окупљање свих србистичких катедара и разговор о отвореним проблемима наставе Српског језика и књижевности, на свим образовним нивоима. Могли бисмо имати редовно, годишње окупљање, све до тренутка док се постојеће разлике не сведу на разумну меру, а сарадњу би вредело наставити и после тога. За почетак би било добро да универзитетски србистички центри више личе једни на друге, да постоје заједнички називи предмета, да се види шта је наша заједничка обавеза и да се утврди заједнички минимум. Разуме се да ће сваки србистички центар моћи да испољи и своје специфичности, посебно када су посреди изборни предмети (курсеви). Заједнички именитељ у плану и програму не сме бити споран, он мора

12 Овде би се ваљало присетити изворног болоњског процеса и приче о мобилности студента из различитих држава. Наши србистички центри оваквим приступом поприлично ограничавају мобилност студената између наших србистичких центара. Прелазак са једног факултета на други био би условљен полагањем великог броја различитих испита (предмета). То није за похвалу. 
бити видљив и у називу предмета и у његовом програму, али и у обавезној (основној) литератури. Нама се чини да морамо више „личити“ једни на друге. Међууниверзитески, тј. међукатедарски састанци би могли помоћи да се разлике смање и да мобилност студената буде реалност, у правом смислу те речи. Посебно би било добро да се овакав састанак одржи пре новог циклуса доакредитације основних, мастер и докторских студија наших србистичких центара.

Ништа боља ситуација није ни на учитељским (педагошким) факултетима у Србији и у Републици Српској. У Србији данас будуће учитеље образујемо у Београду, ${ }^{13}$ Сомбору (Универзитет у Новом Саду), Врању (Универзитет у Нишу), Лепосавићу (Универзитет у Приштини), Ужицу и Јагодини (Универзитет у Крагујевцу). И Република Српска има Педагошки факултет у Бијељини и Катедру за разредну наставу на Палама (Универзитет Источно Сарајево) и у Бањој Луци (Учитељски факултет). И на овим факултетима је приступ настави Српског језика прилично различит. „Српски језик, без сумње, на овим факултетима нема статус какав би морао имати с обзиром на то какву и колику улогу имају садржаји српског језика у првим четирима разредима основне школе“ (Ковачевић 2012: 19).

Чини се да су проблеми још већи и неуједначеност очигледнија на филолошким и филозофским факултетима на којима се изучавају стране филологије. Заправо, имамо студијских група где се школују будући професори страних језика, а да они у току свог универзитетског школовања (пет година, десет семестара) немају ниједан

13 Учитељски факултет у Београду има два истурена одељења, једно у Вршцу, друго у Новом Пазару. Остаје нејасно због чега Државни универзитет у Новом Пазару нема учитељски (педагошки) факултет, већ то чини Универзитет у Београду, преко истуреног одељења Учитељског факултета. 
обавезни курс, па ни час из Српског језика. Овде би се прво морао увести Српски језик као обавезан наставни предмет и додатно понудити изборни курсеви чији би садржаји били функционална писменост, култура изражавања и правопис српског језика. Ову тврдњу не би било тешко доказати. Овде је реч и о наставном и о научном приступу, па је тврдња М. Ковачевића посве тачна: „При том се свјесно пренебрегава чињеница да филолози који се научно баве страним језиком своје најврједније, ако не и једино вриједне, резултате постижу контрастирањем српског језика са неким страним језиком, а за таква (типолошка или поредбена) истраживања познавање бар основа и специфичности структуре српског језика јесте нужан услов“14 (Ковачевић 2012: 20).

$\mathrm{Ha}$ наставничким нефилолошким факултетима наших универзитета нема Српског језика као наставног предмета. Занимљиво је да сви имају страни језик, најчешће по избору, мада енглески језик има примат. Сасвим је очекивана чињеница да на наставничким факултетима имамо страни језик, али је нејасно како Српског нема ни као изборног. И кратким увидом у наставне програме наставничких нефилолошких факултета и ненаставничких факултета у целини можемо се запитати како се нашло места за различите предмете и курсеве који нису директно везани за одређену струку, а Српског језика, функционалне писмености и културе изражавања нема. Ово је питање о коме вреди разговарати и проблем који се мора решити. Можда би за почетак вредело кренути са

14 Не треба посебно објашњавати у каквој су предности професори страних језика ако на часовима могу правити поређења са српским језиком и из тога изводити одговарајуће закључке и снажити ученичко знање и у српском и у страном језику. За то је нужно да добро владају и српским језиком. С обзиром на то да је настава српког језика у средњим школама запостављена, неће бити добро ако се наставници страних језика ослоне само на знање српског језика стечено у основној школи. 
изборним предметима на ненаставничким факултетима, док бисмо на наставничким нефилолошким факултетима одмах, без изузетка, могли увести предмет који би за предметност имао наставу српског језика.

На укупно стање, тј. на место и улогу Српског језика и његов статус у образовном систему и друштву уопште указивао је и Предраг Пипер. Тако је у раду Срйски језик између великих и малих језика (Пипер 2016) скренуо пажњу на неколико основних тачака, а ми овде издвајамо оне које су најближе нашој теми: 1. У Србији надлежна министарства не воде скоро никакву језичку политику. 2. Неписменост великог броја грађана чини нашу реалност. 3. Недовољна је заступљеност предмета Срйски језик у образовању. 4. Маргинална је заступљеност истраживања о српском језику у Стратегији научног и технолошког развоја у Србији. 5. Постоји стихијски продор великог броја непотребних страних речи. 6. Видна је идеологизованост језика и све већа улога језика политичке (не)коректности. 7. Очигледно је потискивање ћирилице из јавне и службене употребе. 8. Морамо се одупрети уништавању ћириличког наслеђа. 9. Не смемо дозволити ревизију историје српског језика и писма (Пипер 2016).

Ипак, и поред свега радују неке најаве, радују неке акције и верујемо да ће Српски језик у систему нашег образовања поново имати место и улогу које му припада. Радују акције Негујмо српски језик и Сачувајмо српски језик, као и јасно дефинисан статус Српског језика у Стратегији развоја културе Републике Србије од 2017. до 2027. (нацрт).

\section{5. Закључак}

1) Око места и улоге Српског језика као наставног предмета у образовном систему Србије на српском језич- 
ком и културном простору морамо постићи национални консензус. Место и улога матерњег језика не смеју бити спорни, можемо се угледати на оне који су овај проблем одавно решили и морамо и ми бити свесни значаја Српског језика за идентитет нације и њене културе у целини.

2) Можда бисмо проблем решили ако бисмо искористили проверене и познате моделе, на које је указала Рајна Драгићевић. „Задатак надлежних за питање статуса Српког језика у школи јесте да се изборе за његов надпредметни статус“ (Драгићевић 2015: 122).

3) У млађим разредима основне школе, од првог до четвртог разреда, број часова се мора осетно повећати. И ту можемо видети статус матерњег језика у окружењу и њихов статус код озбиљних и одговорних европских држава. Зашто се и овде не бисмо позвали на развијену и културну Европу?

4) Када су у питању старији разреди основне школе, од петог до осмог разреда, повећање броја часова Српског језика остаје као императив. Ипак, можда бисмо за почетак могли увести и неке изборне предмете и ученике „приволети“ програмским садржајима које нуди Српски језик и оно што иде уз његову предметност.

5) Чини се да је стање у средњој школи ургентно и да се овде хитно мора реаговати. Настава језика у нашим средњим школама, од гимназија до стручних школа (четворогодишњих и трогодишњих) потпуно је маргинализована, па нерешавање и одлагање овог проблема може имати озбиљне последице. За почетак се мора обезбедити реализација постојећег (предвиђеног) фонда часова, а после вреди размишљати и о другим идејама и унапређењу наставе новим садржајима.

6) Неуједначен приступ очигледан је и на универзитетском нивоу. Прво бисмо морали поправити, тј. „уједначити“ стање на србистичким катедрама и педагошким (учитељским) факултетима. Потом би на ред стигле стране филологије и наставнички факултети, и на крају бисмо стигли до ненаставничких факултета. 
7) Убеђени смо да је ово наш заједнички задатак у наредном десетогодишњем периоду и да садашњим и будућим ученицима и студентима дугујемо да се Српском језику као наставном предмету врате место и улога који му припадају, да му се врати одузето достојанство и да Српски језик добије надпредметни статус. То није ни минимум ни максимум - то је оптимум и то је наш заједнички задатак и наша заједничка обавеза. Верујемо да можемо и морамо бити одговорни.

\section{Литература:}

Брборић 2004: Вељко Брборић, Срйски ӣравойис у настиавној ирракси, Филолошки факултет: Београд.

Брборић 2015: Правойис и школа, Друштво за српски језик и књижевност Србије: Београд.

Брборић 2016: О срйском йравойucy, Друштво за српски језик и књижевност Србије: Београд.

Драгићевић 2015: Рајна Драгићевић, „Нека питања организације наставе српског језика као важан фактор очувања идентитета српског језика и културе“, Узgанииа, год. XII, бр. 1: Јагодина.

Ковачевић 2012: Милош Ковачевић, „Статус српског језика на српским универзитетима“, Филолоїија и универзийей, (Тематски зборник радова), Наука и савремени универзитет 1, Филозофски факултет: Ниш, 13-16.

Пипер 2016: Предраг Пипер, „Српски језик између великих и малих језика“, Кюижевности и језик, год. LXIII, бр. 1-2, Београд.

Станојчић-Поповић 2008: Живојин Станојчић и Љубомир Поповић, Грамайика срйскоі језика за іимназије и среgне школе, Завод за уџбенике: Београд (једанаесто издање).

Стевановић 1977: Владимир Стевановић, Настиавни йланови и йроірами срйскохрватискоі језика и книжевностии за основну школу у СР Србији, Републички завод за унапређивање васпитања и образовања: Београд. 
Veljko Ž. Brborić

University of Belgrade

Faculty of Philology

\section{PLACE AND ROLE OF THE SERBIAN LANGUAGE AS A COURSE IN EDUCATION SYSTEM}

\section{Summary}

This work is about the status of the Serbian language as a teaching subject in the education system - from primary school to university. In fact, it is about the presence of the Serbian language in curricula from primary school to university education. We will make a brief review of the past of this problem, as well as comparison with some of the languages in the environment. We will also talk about some suggestions on how to improve the status of the Serbian language in the education system. According to our knowledge, the worst situation is in the younger grades of elementary school, but also in the older grades of elementary school and in high school we are lagging behind the languages in the environment and the major countries in Europe. The status of the Serbian language at the university level outside the philological / philosophical and teacher education faculties has not been resolved.

Key words: Serbian language, education system, number of lessons, curricula. 